\title{
Governed by Circumstances as They May Arise: A Short Reflection on The Knowledge School and its Context
}

\author{
Jennifer Weil Arns \\ University of South Carolina
}

Abstract: As technologies have moved forward and cultural assumptions have changed, we find ourselves at a moment of opportunity. Our sense of the word libraryis drawn from a rich array of service traditions and a value proposition based on the belief that libraries help those who use them advance in life, engage with others in their communities, and learn more about themselves and the world around them. The Knowledge School concept builds on this assumption and expands it with a broader challenge - a commitment to creating public value, changing communities, and educating those who feel a personal commitment to dealing with the messy complexities of today's social arrangements. This intriguing idea holds much promise; and if the possibility of success is adequate to drive performance, it is likely to lead to a new and vibrant vision that will support changes in the way we think of libraries and where we are when we are working in them.

Keywords: knowledge school, education, public value, community engagement, information society

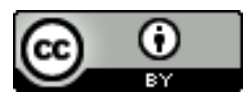

This is an Open Access article distributed under the terms of the Creative Commons Attribution 4.0 International License (http://creativecommons.org/licenses/by/4.0), which permits unrestricted use, distribution, and reproduction in any medium, provided the original work is properly cited. 
In 1852, when Edward Everett and George Ticknor prepared their report (Boston Public Library, 1852) concerning the need for a library to be established in the city of Boston, they spoke to many of the purposes of libraries of today, but not all. They envisioned a retreat: one that would serve the needs of the historian and nourish the mind of the scholar. The collection would also afford "the reading community, (in which we include persons desirous of obtaining knowledge or an agreeable employment of their time from the perusal of books)" (Boston Public Library, 1852, p. 7) with the means to pursue these activities and extend the benefits of their public school experiences. Circulation, a liberal concept, is seen as a critical element in obtaining these goals. Children and women receive passing mention as those to whom these benefits should be extended. Points are made that distinguish between value to the community and value to individual members. The noun Librarian is mentioned twice: once in relation to selling surplus books and once in terms of a request for frugal expenditures related to the purchase of books and the compensation of the librarian (Boston Public Library, 1852).

As Garrison (1979) and Stauffer (2016) note, the individual who was likely to hold this title over the next few decades was likely to be a socially elite New England male, if he emerged as a social or intellectual leader. Females were also acceptable, if they were of sound character. Both groups were also well educated. Fifty percent of the library leaders that Garrison studied were college graduates, typically from New England colleges. Dewey, we are told, encouraged women who might otherwise have been teachers to consider librarianship because the work was less physically demanding. These and other genteel aspects of the profession were expected to compensate for salaries that often compared unfavorably to those of male librarians and urban teachers. More serious consideration of the preparation required for librarianship was also unsurprisingly spearheaded by Dewey. Looking once again to the libraries in Germany, one sees an interesting entry in the landmark 1876 study Journal of New Librarianship, 4(2019) pp. 328-335 10.21173/newlibs/7/4 
Public Libraries in the United States (xxiii) that quotes remarks from Dr. F. Rullmann, Librarian of the University of Freiburg, who notes that "it is very desirable that library science should, more than has been the case hitherto in Germany, form a subject of discussions at meetings of librarians, and that one of the thoughts to be discussed should be whether library science is to form a special branch of study at Universities" (p. 23). The ideas behind these statements speak to production issues related to reliable and replicable systems, efficiency, the accretion of knowledge, succession, and tradecraft. As Dewey put it, as quoted in Trautman (1954), "If it be true, as is so often stated, that 10,000 volumes catalogued and administered in the best way are more practically useful than 30,000 treated in an unintelligent or inefficient manner, then it is of the greatest importance to advance by every possible means the general standard of library work throughout the country” (p. 9).

By the early part of the $20^{\text {th }}$ century, the contours of librarianship had changed dramatically. Public services were extending to a farm population that numbered nearly 32 million, or 30.2 percent of the 1920 total population of 105.7 million people (Banks \& Kalbache, 1980). When Nason (1928) addressed this topic in Farmers'Bulletin No. 1559, he began his discussion with consideration of the many factors that had recently led to changes in rural life: the telephone, rural free delivery, the phonograph, consolidated schools, consolidated markets, the development of the automobile, and a new appreciation of the social role of agriculture. There was little doubt concerning his intended audience. They were the families headed by a "small capitalist who himself works his land, free from the restraints and traditions of peasantry, a whole some home-maker, a self-acting generous partaker in society, a sympathetic counselor with nature, and a conscious keeper of the land for his fellow men" that Bailey (1927, p. 113) looks forward to seeing. The services intended to promote these goals include aspects of the libraries we know today: county library systems, bookmobiles, circulating collections, and standardized classification systems. 
In urban centers, populations had become less homogenous, and the information needs and uses of those who lived in a more multi-layered society propelled socially conscious experiments such as the Saturday Evening Girls pottery project started by Helen Storrow, a wealthy Boston philanthropist, and the community activities sponsored by Ernestine Rose, the forward thinking librarian who aided European immigrants on the Lower East Side of Manhattan and contributed to the founding of the Schomburg Center for Research in Black Culture in Harlem. In the South, a group of southern librarians met prior to the 1920 American Library Association Conference in Colorado Springs to "tackle two pressing problems--library service for Blacks and training facilities for black librarians" (Southeastern Library Association, n.d., para. 3). Although progress was slow, by 1928, the Rosenwald schools were providing minimal public library services in much neglected African American Communities. In 1926 the Carnegie Corporation funded the first Graduate Library School at the University of Chicago. Graduate education soon found a home at Columbia University (Richardson, 2010).

More recent technological advances have clearly expanded the public service capacity of public libraries and inexorably transformed library and information science curricula. Bates (2004) remembers heady days at the University of California at Berkeley in the 1960s where she came to grips with the concept of information science while working with Bill Maron, William Cooper, Victor Rosenberg, and Michael Buckland.

Writing in equally exciting times, Saracevic (1979a), points to significant technology developments, but cautions that the "rapid and rather chaotic evolution of information science has left the field's academic sector in a largely disorganized state" (p. 1). He also raises a somewhat troubling issue - that the rapidly evolving technologies of that era often seemed to proceed without a clear sense of their application or how they might be used to develop theory or respond to pressing Journal of New Librarianship, 4(2019) pp. 328-335 10.21173/newlibs/7/4 
needs. In a second paper (1979b), Saracevic points to two other trends: the interdisciplinary diffusion of information science courses and programs and the substantial number of cases where information science appears to be merely a euphemism for computer science. Writing more recently, Losee (2017) suggests that the Library Science programs that have moved toward "Information Science" have largely done so as information technology programs, while "the dividing line between these and computer science departments has become fuzzier over time” (p. 2).

The important question remains finding the right model. Few would argue that Nason's goals lack enduring value. There are also few who would argue with the reflection that a number of dramatic social, economic, and technology factors are currently changing rural and small town life in America. The same may be said of the libraries and cultural institutions that promise to enrich the lives of the individuals who live in these communities; and the success of these efforts will depend on several factors, including the dedication and skills of those to whom these institutions are entrusted. In the case of small community and rural libraries, figures vary, but it is likely that these libraries number over 30,000 , and those who live in their service areas, number over $75,000,000$. In many of these cases, regionalism is important. Community ties tend to be valued, and unique collections of artifacts contribute to proud identities; but there are also problems. Nor can one put aside the concepts that fortify information science. Economic revitalization has proved the value of a skilled and technologically literate workforce, and the understandings that fall within the iSchool umbrella continue to fuel vital urban clusters and experiments in new types of virtual and physical communities. Although regional and rural disparities are likely to persist as super firms gravitate to urban areas with deep talent and capital reserves (The Economist, 2016a; The Economist, 2016b), there is also a pervasive sense of optimism that suggests that improvement in fields such as medical informatics and manufacturing will lead to favorable advances. 
Within this context, the promise of the Knowledge School concepts lies in consequence rather than reconciliation: an explicit commitment to use technology, theory, and knowledge to sustain and create public value. Although like most constructs, this phrase falls short of precision. Bryson, Crosby, and Bloomberg (2014) provide helpful markers: a response to the challenges of a messy networked, multi-sector, no-one-wholly-in-charge world; a way of looking at things that looks beyond efficiency and effectiveness to democratic values; a place where public agencies and government are guarantors of public values; and a place where citizens and multiple organizations join together to become active public problem solvers. Alford and Hughes (2008) point to another dimension, the commitment to collective public value. However, they also point to two of the challenges that a Knowledge School will face - weighing the merits of collective and subgroup preferences that change quickly over time and choosing the right metrics and value propositions. At the individual level, some of these are intuitive: actions that help me advance in life, engage more fully in my community, and learn more about myself and others.

At the community level, this will be harder. Tools such as the OECD wellness measures (housing, income, jobs, community, education, environment, civic engagement, health, life satisfaction, safety, and work life balance (Organisation for Economic Co-operation and Development, n.d.)) can be used to assess collective conditions and characterize the experiences of larger social and geographic units. We also see that we are still on sure footing when we return to Ticknor and Everett's proposition that "the question is not what will be brought about by a few individuals of indomitable will and an ardent thirst for improvement, but what is most for the advantage of the mass of the community" (Boston Public Library, 1852, p. 9). This statement speaks to one of the most distinctive aspects of the Knowledge School concept, as does the idea of heeding to circumstances as they arise. The devil will be in the details. 


\section{References}

Alford, J., \& Hughes, O. (2008). Public value pragmatism as the next phase of public management. The American Review of Public Administration, 38(2), 130-148.

Bailey, L. H. (1927). The harvest of the year to the tiller of the soil. New York: Macmillan.

Banks, V., \& Kalbache, J. (1980). The changing U.S. farm population. Rural Development Perspectives. March, 43-46. Retrieved from https://naldc.nal.usda.gov/download/IND43755883/PDF

Bates, M. (2004). Information science at the University of California at Berkeley in the 1960s: A memoir of student days. Library Trends, 52 (4), 683-701.

Boston Public Library. (1852). City Document No. 37--Report of the trustees of the public library to the city of Boston, 1852. Retrieved from https://archive.org/details/uponobjectstobea00bost

Bryson, J. M., Crosby, B. C., \& Bloomberg, L. (2014). Public value governance: Moving beyond traditional public administration and the new public management. Public Administration Review, 74(4), 445-456.

Department of the Interior, Bureau of Education. (1876). Public libraries in the United States of America; Their history, condition, and management. Special report. Part 1. Washington: U.S. Government Printing Office. Retrieved from https://archive.org/details/cu31924029529553/page/n4

Garrison, D. (1979). Apostles of culture. New York: Free Press.

Losee, R. M. (2017). Information theory for information science: Antecedents, philosophy, and applications. Education for Information, 33(1), 23-35.

Nason, W. (1928). Farmers' Bulletin: No. 1559. Rural Libraries. Retrieved from https://digital.library.unt.edu/ark:/67531/metadc5941/m1/1/ 
Organisation for Economic Co-operation and Development. (n.d.). Measuring well-being and progress: Well-being research. Retrieved from http://www.oecd.org/statistics/measuring-well-beingand-progress.htm

Richardson, J. (2010). History of American library science: Its origins and early development. In M.

Bates \& M. Niles (Eds.), Encyclopedia of library and information sciences. (pp. 1-9). Boca Raton, FL: CRC Press.

Saracevic, T. (1979a). An essay on the past and future (?) of information science education-l: Historical overview. Information Processing \& Management, 15, 1-15.

Saracevic, T. (1979b). An essay on the past and future (?) of information science education-Il: Unresolved problems of "externalities" of education. Information Processing \& Management, $15,291-301$.

Southeastern Library Association. (n.d.). A signal accomplishment-The 1920's. Retrieved from http://www.selaonline.org/sela/history/1920.html

Stauffer, S. (2016). The work calls for men: The social construction of professionalism and professional education for librarianship. Journal of Education for Library and Information Science, 57(4), $187-291$.

The Economist. (2016a). The great divergence; Varieties of inequality. Retrieved from https://www.economist.com/united-states/2016/03/12/the-great-divergence

The Economist. (2016b). The rise of the superstars; Companies. Retrieved from https://www.economist.com/special-report/2016/09/17/the-rise-of-the-superstars

Trautman, R. (1954). A history of the school of library service, Columbia University. Retrieved from https://archive.org/stream/historyofthescho011560mbp/historyofthescho011560mbp djvu.tx $\underline{\mathrm{t}}$ 
Williams, I., \& Shearer, H. (2011). Appraising public value: Past, present and futures. Public Administration, 89(4), 1367-1384. 